\title{
The Contribution of Internal Audit to the Improvement of Internal Control System
}

\author{
El Azhary Najah \\ Research laboratory: Finance, Bank and Financial markets \\ Mohamed V University of Rabat, FSJES of Sale/Morocco
}

Taouab Omar

Thesis director

Doi: 10.19044/esj.2018.v14n7p200 URL:http://dx.doi.org/10.19044/esj.2018.v14n7p200

\begin{abstract}
In order to be more flexible in a perpetual mutational environment and face up to damaging effects of an economic situation in strong growth, organizations have to acquire efficient management tools allowing them to accomplish their objectives and to protect themselves against inherent risks. The implementation of an internal control system is considered to be the guarantor of an invincible organizational system and a means of control of risky operations. However, an applied and well conceived internal control provides the organization just a reasonable and not an absolute insurance about its objectives realization and sustainability.

It is the reason for which an upper level control, accomplished by the internal audit function, seems to be a palliative to the internal control deficiencies, and a means of supervising and evaluating the application of procedures and internal control rules. Thus, this research aims at demonstrating how internal audit can participate to the improvement of internal control system. In this context, we have introduced a qualitative study, which was based on a sample of 10 Moroccan publicly traded companies that operate in many industries. Through the interviews conducted with this sample, we had identified firstly, the different control levels within organizations, and their degree of effectiveness and their capacity to face up risks as well as the limits of each type of control. Secondly, this research explored that internal audit is considered as a response to the insufficiencies of different lower control levels, and a means of monitoring and piloting the effectiveness of internal control system, across notably the recommendations provided
\end{abstract}

Keywords: Internal audit, internal control, risks, procedures, recommendations. 


\section{Introduction:}

In an environment in perpetual mutation and vigorous increase, managers are compelled to adapt themselves to these changes by being flexible in their manner of managing both inside and outside the organization.

In this context, organizations have to acquire management tools allowing them to accomplish their objectives efficiently; amongst we find the implementation of an internal control system, which will be constituted of all means and actions allowing the organization to master its risky operations.

This system can work efficiently if only internal control rules and principles are applied properly.

Yet, further to the existence of brakes restricting the proper functioning of the internal control system, considering that this system cannot transform a bad manager into a good one, it seems primordial that an upper level control, it means, a third level one is important and must be implemented in order to verify and evaluate the application of procedures and internal control rules by all the organization's actors.

In this perspective, our research problem will consist in demonstrating to what extent we can consider the third level control, provided by internal audit, as a response to the insufficiencies detected at the different lower control levels, and how can this control participate to the implementation of a performing internal control system.

In response to this research problem, it appears judicious to start first of all with the presentation of internal control system and internal audit, before announcing the main theories and authors having shown the contribution of internal audit in the improvement of internal control system. Then, we are going to introduce a qualitative study, which will be based on a sample of 10 Moroccan firms, and that will aim at identifying firstly the different control levels within organizations, and their degree of effectiveness and their capacity to face up risks as well as the limits of each type of control. Secondly, our objective will focus on understanding how internal audit can participate to the implementation of an effective internal control system, and how it can be considered as a response to the insufficiencies revealed at the different lower control levels.

\section{Presentation of internal control system:}

\subsection{Definition of internal control:}

According to INTOSAI standards, the internal control is defined as: [3]“ An integral process that is effected by an entity's management and personnel and is designed to address risks and to provide reasonable assurance

[3] Fr. VANSTAPEL. Lignes directrices sur les normes de contrôle interne à promouvoir dans le secteur public, 2001. [En ligne] Disponible: http://www.partagedesconnaissancesbw.be/attachment/425249/ 
that in pursuit of the entity's mission, the following general objectives are being achieved:

- Executing orderly, ethical, economical, efficient and effective operations;

- Fulfiling accountability obligations;

- Complying with applicable laws and regulations;

- Safeguarding resources against loss, misuse and damage.

Internal control is composed of a set of actions related to an entity's activities, it is a management tool that focuses on reaching the organization's objectives.

This system comprises a range of means, behaviours, procedures and actions adapted to the specific characteristics of each organization.

The internal control system contributes to the control over of the company's activities, to the efficiency of its operations and to the efficient use of its resources. It must also allow the organization to take into account significant risks relevant to the achievement of its objectives, whether operational, financial or compliance-related.

Furthermore, internal control is not limited only to accounting and financial processes, it takes into consideration the whole processes and procedures.

\subsection{Components of internal control:}

Internal control is composed of five interrelated elements, among which we name:

- Control environment

- Risk assessment

- Control activities

- Information and communication

- Monitoring

The control environment is considered as the cornerstone of an efficacious internal control system, it is an influencial determinant of the global quality of internal control, and affects the way with which the strategy and the objectives are determined.

This component of internal control is considered by underlying standards as "The attitude and actions of the board and management regarding the significance of control mechanism within the organization".

Besides, it provides the necessary discipline and structure for the achievement of the primary objectives of the internal control system.

According to the same standards, the control environment includes the following elements:

- Integrity and ethical values;

- Philosophy and direction style; 
- Organisational structure;

- Assigning authority and responsibility

- Human resource policies and practices.

- Commitment to competence

After the implementation of a strong control environment, it seems primordial to conduct the risk assessment that consists in identifying and analyzing relevant risks. This analysis may help the organization to reach its objectives and to find the appropriate response to the risks detected.

The minimization of these risks is conditioned absolutely by the introducing of control activities that will serve as a means of risks prevention and detection, and must be completed by corrective actions. Thus, the costs of the measures adopted to achieve this target should not exceed their benefits.

So as to fulfil its purposes and to better control its operations, the organization must choose a punctual and an efficient strategy of information and communication. This is across notably relevant and appropriate communication, as well as reliable and exhaustive internal and external information, which must be accessible to all the hierarchical levels.

The internal control system should be monitored in order to assess the quality of the system's performance over time, and to reach the organization's objectives and to encounter risks and abrupt changes as well.

\section{3 Limitations on internal control effectiveness}

An applied and well conceived internal control provides the organization just a reasonable and not an absolute insurance about its objectives realization and sustainability. Thus, it will neither transform a bad manager to a good manager, nor control changes that can happen at the macroeconomic level.

Those changes oblige managers to review and update controls and adjust the level of acceptable risk.

Inspite of the fact that internal control system reduces the probability of not reaching organization's targets, it will never eliminate the risk that this system will be badly conceived or will not function properly.

This can happen because internal control system is conceived by human factor, which can make it exposed to flaws in design, errors of judgment or interpretation, misunderstanding, carelessness, tiredness or distraction, collusion, abuse or override.

This is the reason for which the top management must reinforce controls that allow the organization to be ensured of the better functioning of internal control system, and to conduct changes that can influence the organization effectiveness. 
In this context, the evaluation of internal control system is carried out by the internal audit function of the organization, which presence seems to be a good palliative to the aforementioned limitations.

\section{Reflexion on internal audit:}

\subsection{Genesis and functioning of internal audit:}

The term audit comes from latin "Auditus"[4], that means to "listen ", which history goes back to several centuries before J.-C according to some historians. In this period, it was limited just to some verifications and accounting reviews. For other historians, the origin of Internal Audit function is most often linked to the creation of the Institute of Internal Audit (IIA) in the United States of America in 1941, then to the creation of the statement of responsibilities of the internal auditor.

This profession has known a remarkable evolution in response to numerous financial scandals and technological advances, which has generated the proliferation of laws and regulations that the auditor must verify the application, in order to avoid the organization inherent risks.

Then, internal audit has expanded to other countries such as: England, China, France... Besides, France has promoted this profession and has given it more legitimacy by creating the French Institute of Internal Auditors and Controllers (IFACI).

Several achievements have made from internal audit a normalized international profession, and accelerated its growth and globalization, among which we find, the approval of the Standards for Professional Practice of Internal Audit set by the Institute of Internal Auditors, and the creation of the European Confederation of internal audit institutes. Those actions were followed in 2009 by the publication of the new International Professional Practices Framework of the Institute of Internal Auditors, that contains the obligatory dispositions such as the definition of internal audit, the International Standards for the Professional Practice of Internal Audit and the Code of Ethics, as well as the highly recommended dispositions.

The internal audit scope has gained in credibility and maturity and has expanded to several fields, and covered all the organization's functions and activities, with a relatively high frequency. Indeed, internal audit has extended to all sectors, all firms and associations of all sizes.

It is not perceptible anymore as a financial function, it provides the organization to assess the level of internal control system, and accompanies audited entities in the process of management of their activities across notably the process of issuance recommendations.

[4]Elisabeth, B. E. R. T. I. N. (2007). Audit interne: enjeux et pratiques à l'international. Editions d'Organisation Eyrolles. 
Its independence increased by its direct attachment to the top management, combined with its strong relationship with the audit committee or a similar organism. The internal audit value added is determined across the objectivity of the audit findings and the relevance of the recommendations made.

In Morocco, the Internal Audit Function appears at the end of the eighties, in response to a growing government willingness, which aimed at implementing and reinforcing transparency and good governance practices within the organizations forming the Moroccan economic structure[5].

In spite of the fact that Moroccan context was isolated from economic crisis and recessions that took place in many countries of the world, due to its underdeveloped economic status and its less opened international position, Morocco tried to be protected from these economic vagaries which constitute indeed the main effects of globalization.

Besides, the public sector and the state-owned companies are the pioneer and the first to adopt the internal audit function, so, this discipline participated to the proper management of the public funds and has led to a better international opening.

The main objectives discounted behind its creation were to improve the financial statement of these firms, in response to the recommendations formulated by financial donors as part of the Structural Adjustment Program (SAP).

This function has generalized to other economic sectors, so as to implement and to strengthen Corporate Governance best practices to all Moroccan organizations.

To that it is added, the necessity to protect the interests of those who invest their talents and their capitals in the benefit of the economy, in a globalization context and exacerbated competition.

In fact, the strengthening of Internal Audit function in Morocco became a reality in 1985, through the creation of Moroccan IIA, which is a Moroccan association of the internal consultant auditors (AMACI).

Which was followed in 1993 by a royal incentive in order to adopt this profession to all companies, notably the public ones. His late Majesty king Hassan II reported in a letter addressed to the Prime minister: [6] « Audit is nowadays a common practice in societies and firms. You have to implement it in all the public establishments ». (The economist newspaper, Edition $\mathrm{N}^{\circ} 3$ of 14/11/1993).

[5]Najah, E. (2016). Les Déterminants de l'Indépendance De l'Auditeur. European Scientific Journal, ESJ, 12(34).

[6]Barnia, M. (2015). La création de valeur ajoutée socio-économique par L'Audit Interne: Cas d'Entreprises Marocaines(Doctoral dissertation, Conservatoire national des arts et metiers-CNAM). 
Despite the fact that the application of this royal request confronted numerous problems, linked notably to the unsuitability of the human resources assigned to auditing function, and to the inadequacy of financial and material resources necessary for the accomplishment of this mission in the best conditions, the directives dictated by the Prime Minister were taken into account by all the ministries.

The Institute of Internal Auditors (IIA) defines internal audit in 1999 as following[7] [8]: « Internal audit is an independent, objective assurance and consulting activity designed to add value and improve an organization's operations. It helps an organization accomplish its objectives by bringing a systematic, disciplined approach to evaluate and improve the effectiveness of risk management, control, and governance processes. »). This definition was adapted by IFACI.

This definition focuses first of all on the independence and objectivity as the sine qua none conditions of the internal audit success, which mission consists in evaluating the internal control system, by proving if the internal control targets are reached or not. The first version of the internal control objectives allowed to categorize them into 3 types, thus, we distinguish:

- Operational objectives: they consist in ensuring the realization of operations and the improvement of performance, as well as the optimization of financial, human, informational, material and structural resources, and their use in an efficient and effective way.

- The objectives of the reliability of financial information.

- The objectives of compliance with applicable laws and regulations.

Other objectives assigned to internal control have been added by COSO II. These include strategic objectives, objectives of achieving and optimizing operations, including performance and profitability targets, objectives of reliability of the internal and the external, financial and non-financial information, and the objectives of compliance with applicable laws and regulations.

In that regard, for each internal control objectif, there have been assigned internal audit missions. To this effect, we can find operational auditing missions, financial auditing missions and strategy auditing missions.

- Operational auditing missions [9] consist in assessing compliance with written procedures and ensuring the effectiveness of the organization. The auditor main concern will be to conduct tests and reviews of an organization's activities and processes, in order to detect deficiencies and to evaluate the organization's

[7]Olivier, L. E. M. A. N. T. (2003). l'audit interne, édition e-theque.

[8]Reding, K. F. (2015). Manuel d'audit interne: améliorer l'efficacité de la gouvernance, du contrôle interne et du management des risques. Editions Eyrolles.

[9]Bécour, J. C., \& Bouquin, H. (1996). Audit opérationnel: efficacité, efficience ou sécurité. Economica. 
accomplishments, so as to palliate the insufficiencies noted and to follow up the recommendations made.

- Financial auditing missions consist in ensuring that the internal control financial objectives and procedures are respected and reliable, with the external auditors' collaboration, without affecting the perimeter of financial statements certification mission.

- Strategy auditing missions consists in assessing the relevance of the objectives and strategic orientations of the organization, and identifying the risks associated to that. It takes into account also the performance assessment by comparing forecasts to achievements.

Moreover, according to Ronald (2006), four control levels corresponding to the ages of the internal audit can be associated with the aforementioned missions. We distinguish for this purpose[10]:

- The compliance audit or the regularity audit: It consists in checking the correct application of procedures and the adherence to rules, laws, regulations, standards, posts descriptions...

- The efficiency auditing: it consists in ensuring the conformity of the procedures and rules in place with the existing standards, and seeks to evaluate the capacity of these rules to achieve the organization's objectives.

- The management auditing: its role is to evaluate the choices and decisions taken by the organization as well as their consequences, in order to identify potential risks and inconsistencies related to them.

- The audit of strategy (Naaima 2004): Its role is to assess and decide on the relevance of the organization objectives, and their degree of coherence with the organization purposes and finalities. In effect, this type of audit tends to develop due to the importance of decisions and strategic choices, and their considerable impact on the survival and continuity of the organization. It represents the developed level of the audit function, and required from internal auditors to hold a high experience level.

The creation of the internal audit function is often associated with several determinants, among which we can note the size of the organization, the dispersion or geographical distance, or the importance of the organization's activity. In fact, Van Cutsem (1999) estimates that an audit service becomes mandatory when the organization reaches one thousand employees.

Furthermore, when the organization has several distant and dispersed subsidiaries, the creation of an internal audit department becomes more judicious, and will have as a major concern to ensure that the procedures implemented and the decisions taken at the headquarters level are correctly applied at subsidiary level.

[10]Renard, J. (2016). Théorie et pratique de l'audit interne: Primé par l'IFACI. Editions Eyrolles. 
As the internal audit function attachment is concerned, some organizations make the internal audit department dependent on an operational direction, in particular the administrative and financial one, which places it at a lower level than an operational department. This linkage will allow a better technical monitoring of the operational department; however, it can impair the audit effectiveness and compromise its impartiality and independence.

In this perspective, best practices consider the attachment of this function to a higher level, one of the solutions that can extend the scope of the internal audit function, and a guarantee of its independence. The standard number 1110 stipulates that [11]"The chief audit executive should report to a level within the organization that allows the internal audit activity to fulfil its responsibilities. The chief audit executive must confirm to the board, at least annually, the organizational independence of the internal audit activity“.

In effect, the auditor independence represents the principal condition of the auditor's objectivity, that enables him to exercise his mission under better conditions, it is considered as the key factor of success of the Internal Audit function.

In order to ensure the internal audit independence, this function must be attached to the highest authority level, which can guarantee for it a broad scope of action and a better accomplishment of audit missions, as well as a good follow-up audit recommendations. In fact, the underlying standards recommend that the internal audit function should be functionally linked to the audit committee and hierarchically to the General Management.

According to the same standard, the functional attachment implies that audit committee:

- Approves the internal audit charter;

- Approves the risk assessment carried out by the internal audit, and the audit plan;

- Receive information from the chief audit executive about the results of the internal audit work, or any other matters he considers necessary to communicate in private meetings without the presence of the managers.

- Approves all decisions relating to performance evaluation, appointment or replacement of the chief audit executive;

- Approves the annual remuneration and salary increases of the chief audit executive ;

- Inquire with the management and the internal auditor on possible limitations of the scope of intervention or the budget, likely to prevent internal audit from completing successfully its missions. 
Concerning the hierarchical attachment, it consists in the daily management of internal audit activities, it concerns:

- Budgeting and management accounting;

- Human resources management, including performance assessment and staff remuneration;

- Internal communications and information flows;

- Management of internal audit rules and procedures

This type of linkage allows a high level of fluidity in the information transmission and a better communication with the general management, it contributes also to a good reactivity in the decision-making process. Indeed, according to Renard (2006), such a connection allows the internal auditors "to fully exercise their role as management advisors, in dialogue with the general management and all hierarchical levels".

The attachment to the highest level favours to the auditor to be transversally at the top of the organization, and to be distinguished from other services by asserting his competence over all functions. Nevertheless, this may constrain his impartiality when the anomalies identified and the recommendations made are controversial and inconsistent regarding the General director interests.

In such case, some organizations may opt for both functional and hierarchical attachment to the audit committee or the board of directors, which will reduce in fact the information asymmetry between the general management and the shareholders, and calm down by then the tensions that may exist between the auditors and the managers in the agency relationship, and participate therefore to the institution of a climate of trust between the main governance actors.

\subsection{Methodology and technique of internal audit:}

\subsubsection{The preparatory stage: [12]}

\subsubsection{Review of risk mapping:}

A good internal audit management implies a good mission planning, the planning standard number 2010 stipulates that "The internal audit function must establish risk-based plans to determine the priorities of the internal audit activity, consistent with the organization's goals"'.

Moreover, when planning audit missions, the chief audit executive must take into account risk appetite and risk mapping if these elements are defined by the organization, or opt for its own risk analysis in the case where these parameter do not exist.

[12]Schick, P. (2007). Memento d'audit interne: Méthode de conduite d'une mission. Dunod. 
The audit plan is elaborated on the basis of an assessment of the organization's risks and threats. This evaluation defines the priority risk areas that allow the prioritization of an audit mission over others.

In the case where the organization does not have a risk mapping, the internal auditor carries out an analysis of the process mapping, which constitutes the parameter of identification of events that may impact each of these processes.

The internal audit entity tries to collect the maximum of information about the organization by conducting interviews with all the operational managers and the managing director.

The object of those interviews is to better surround the operational objectives related to every direction, and to discern the major changes encountered by the organization or the potential ones, which will help in the elaboration of the risks mapping, that serves as the basis for the planning of the audit missions.

This planning must be approved by the audit committee, and has to be updated annually.

\subsubsection{Planning of audit missions:}

On the basis of the risk mapping, the chief audit executive can define the processes and topics to be audited, and establish a long-term projected planning, with an annual cutting up, and a biannual updating in case of missions accomplished out of the audit plan.

This plan must be submitted to the audit committee for approval and may be reviewed during the year, particularly when organizational changes take place or new requests come from the top management.

Projected planning represents the tool that assigns each resource to a mission with a given period.

\subsubsection{The phase of acquiring knowledge of the audited process environment:}

Before starting the audit mission, the auditor needs to familiarize himself with the audited process, so, he has to collect the necessary information for a better understanding of the activity and a good prevention of risks likely to threaten the achievement of the organization's objectives. Thus, he must consult:

- The organization chart and function definitions.

- The functions definition

- The flow charts

- The task and function analysis grid

- Manuals of procedures 
- Risk mapping of the audited process

- Important data environmental

- applicable procedures

- The management methods and information system of the audited process,

- Reports of the external Auditors

- Any existing work programs covering the subject to be audited.

- Information on short-term problems facing the organization.

In that case, the information collected will be analyzed in order to comprehend the activity evolution of the audited entity, and to be able to make the comparison between the main activity indicators so as to detect the inherent risks and the disturbing trends.

For a better understanding of the controlled environment, the auditor should conduct interviews with managers, because we cannot find all the information relating to the organization transcribed at the official documents.

The auditor must also use the questionnaire for a better comprehension of the socio-economic, functional and organizational context.

After classifying the collected and exploited information in a permanent file, the auditor makes a preliminary assessment of the apparent strengths and weaknesses.

\subsubsection{The stage of choice of the objectives:}

After preparing the guidance report, which is a document intended for the audited entity, summarizing the auditors conclusions on risk areas as well as the general and specific objectives, the audited divisions, the scope and nature of work to be carried out... the auditor proceeds then to the establishment of an audit program or a work list in order to meet the commitments of this report.

\subsubsection{The stage of implementation:}

This phase starts with an opening meeting to remind the auditees of the expected functioning of the audit mission, and the expected objectives behind its completion.

The auditor will have two objectives to achieve during this phase. He must bring out the apparent strengths and weaknesses of the existing internal control system, that he has identified during the preparatory phase, and must propose to the auditees improvement solutions.

In the meantime, the auditors conduct their audit works in accordance with the agreed work program. The latter may be adapted as the mission progresses, after the approval of the chief audit executive.

Auditors will use audit techniques such as interviews, physical observation, surveys, analytical review, narration, flow chart, task analysis 
grid... and will use audit tools such as internal control questionnaire, Risk Tables, Test sheets, Revelation Sheet and Problem Analysis. Furthermore, the auditees should collaborate with the audit team during this phase, by being available to receive auditors and being reagents, so as to provide them with the necessary documentation in a quick deadline.

During the mission, the auditor should document his work, by developing test sheets that will be supported by the necessary supporting documents, otherwise, the tests will not be considered as completed. This documentation will justify the audit findings, and should allow external readers to reach the same auditor conclusions.

Moreover, the audit findings correspond to a dysfunction or a weakness observed in the internal control system of the audited entity, because either of inexistent control, or improperly designed control, or a control that does not function properly.

Before starting the writing of Revelation and Problem Analysis Sheets (FRAP), the chief audit executive must review the auditors work and verify if the work has been carried out in accordance with the audit procedure. He has also to check if the audit findings and the recommendations related to them are justified.

\subsubsection{The conclusion phase:}

Each audit mission ends with the writing of an audit report in accordance with the standard number 2440 of the Internal Audit Framework (IFACI), which stipulates that 'The chief audit executive must communicate results to the appropriate parties. "

In addition, he is obliged to draw up a definitive report which will be transmitted to the management of the audited activity, and to the organization's members, in order to undertake any corrective action.

The report must announce the audit findings and observations and propose recommendations, which are considered as the results of the verification of the application of a reference system.

During the year $\mathrm{N}+1$, the auditor is obliged to carry out a follow-up mission of implementation of recommendations, in order to ensure that his observations have been taken into account by the audited entity. 


\section{Theoretical reading of the contribution of internal audit to the improvement of internal control system:}

Some authors and theories have demonstrated the contribution of internal audit to the improvement of internal control system, among which we find the agency theory [13],[14].

\subsection{The agency theory:}

An agency relationship is defined by Michael C. Jensen and William H. Meckling (1976) ${ }^{15}$ as "A contract in which one or several persons [the principal] recruits another person [the agent] with the intention of accomplishing a task in his place, which requires a delegation of decision to the agent ".

The agency theory is based on the fact that there is always an asymmetry of information between the signatory parties in a contract. In this case, we find that one party is always better informed than the other one about the contract content. In other words, in an agency relationship, the agentmandatory will have more access to the information than the shareholder representant who is the principal, especially as regards the information coming from the market and not produced by the manager

For this purpose, and in order to be at the same information level as the agent, the principal will be compelled to incur costs such as the costs of monitoring and evaluating the actions and results of the manager.

Indeed, the analysis of the costs generated by agency conflicts leads to deduce the importance of audits and controls in mitigating the interests divergence between these two stakeholders. In addition to the external audit, the internal audit, which is an internal function of the firm, and an emanation of the general management, was not considered by the agency theory as a supervisory mechanism; it was only in 1997-2000 that Charreaux ${ }^{16}$ considered internal audit as a governance mechanism.

In other words, it is on the basis of the internal control system assessment and the evaluation of the application of procedures that the internal audit will issue reports, which provide information on the main anomalies that constraint the proper functioning of the company, and will provide recommendations to palliate the shortcoming identified. These reports are an

[13]Mandzila, E. E. W. (2006). Audit interne et gouvernance d'entreprise: lectures théoriques et enjeux pratiques. Euromed-Marseille Ecole de Management.

[14]Ebondo Wa Mandzila, E. (2004). La contribution du contrôle interne et de l'audit au gouvernement d'entreprise (Doctoral dissertation, Paris 12).

[15]Jensen, M. C., \& Meckling, W. H. (1976). Theory of the firm: Managerial behavior, agency costs and ownership structure. Journal of financial economics, 3(4), 305-360.

[16] Charreaux, G. (2000). Gouvernement d'entreprise et comptabilité. Encyclopédie de comptabilité, contrôle de gestion et audit, 645-656. 
essential tool for shareholders to be ensured that their business is running smoothly, and allowing them to reduce information asymmetry and create a performing internal control system.

\subsection{Other theories:}

According to Gramling and Myers (2006) ${ }^{17}$, internal audit has an important role in corporate risk management, especially in the process of preparing the internal control report. In this regard, it is the best in even to feed the board of directors with information on weaknesses of the internal control system or the areas of risk that may affect the achievement of strategic, operational, informational objectives and compliance.

In the same vein, Fadzil et al. $(2005)^{18}$ considered that internal audit reports provide reasonable assurance of the quality of internal control, and contribute to the achievement of organizational objectives.

Furthermore, Ebondo Wa Manadzila (2007) ${ }^{19}$ and Gramling et al. $(2004)^{20}$ considered that internal audit function can contribute to the reduction of information asymmetry, through its intervention at the improvement of internal control and risk management process.

Morover, Ho and Hutchinson (2010) ${ }^{21}$ argued that effective internal audit reduces agency problems within firms. Indeed, an internal audit function of a good quality establishes an effective internal control system and reduces the opportunism of managers.

In Australia and New Zealand, Coram et al. $(2008)^{22}$ had examined the impact of internal audit quality on fraud detection. They found that organizations with an internal audit function were more likely to detect and prevent fraud than the ones without this function. The aforementioned result revealed that internal audit participate to the creation of added value for the company, notably in terms

[17] Gramling, A. A., \& Myers, P. M. (2006). Internal auditing's role in ERM: as organizations lay their enterprise risk groundwork, many auditors are taking on management's oversight responsibilities, new research finds. Internal Auditor, 63(2), 52-58.

[18] Hanim Fadzil, F., Haron, H., \& Jantan, M. (2005). Internal auditing practices and internal control system. Managerial Auditing Journal, 20(8), 844-866.

[19] Ebondo Wa Mandzila, E. (2007). Internal Audit and Corporate Governance: Theoretical Readings and Practical Issues (Audit Interne Et Gouvernance D'Entreprise: Lectures Théoriques Et Enjeux Pratiques).

[20] Gramling, A. A., Maletta, M. J., Schneider, A., \& Church, B. K. (2004). The role of the internal audit function in corporate governance: A synthesis of the extant internal auditing literature and directions for future research. Journal of Accounting literature, 23, 194.

[21] Ho, S., \& Hutchinson, M. (2010). Internal audit department haracteristics/activities and audit fees: Some evidence from Hong Kong firms. Journal of International Accounting, Auditing and Taxation, 19(2), 121-136.

[22] Coram, P., Ferguson, C., \& Moroney, R. (2008). Internal audit, alternative internal audit structures and the level of misappropriation of assets fraud. Accounting \& Finance, 48(4), 543-559. 
of improving internal control procedures through the fraud detection and prevention.

\section{Empirical verification of the contribution of internal audit to the implementation of an effective internal control system:}

\subsection{Motivation and objectives of the choice of qualitative approach:}

In order to discover how internal audit can contribute to the improvement of the internal control system by making it infallible, it seemed more appropriate to opt for a qualitative study.

Despite the fact that qualitative researches are considered as being opened and complexes, they allow the researcher to deeply understand the phenomena analyzed.

« A qualitative approach allows notably a more total vision, a holistic or systematic one; in even to take into account numerous correlations and their articulation with a particular environment » (Gavard-Perret and al, on 2012: 249).

In fact, our case doesn't differ from the qualitative logic, given that it has as an objective to detect at first the existing control levels within the organizations that belong to the sample studied, and their capacity to cope with the risks to which the company may be confronted, it has as an aim also to present the limits of each type of those controls. Secondly, the objective will be to understand how internal audit can contribute to the establishment of an effective internal control system and to overcome the limits of the aforementioned controls.

\section{2 Methodology and conduct of the exploratory qualitative study:}

This study was based on a qualitative approach. Thus, the data collection method was semi-directive interviews with the chiefs audit executive and the internal controllers of 10 Moroccan companies.

Indeed, we chose this data collection mode as it is the qualitative method the mostly used in management sciences.

Semi-directive interviews are based on an interview guide that identifies the main points to be discussed with the interviewers, without specifying an order to be respected.

In this context, we had prepared an interview guide containing all the axes to be dealt with, in order to collect the information needed to respond to our research question.

These axes are presented as follows:

- General Information: This section aimed at developing a good knowledge about the sample subject of the study, and helped to build a database about it. 
- Control entities available in these companies: The purpose of this section was to identify and make an inventory of the control bodies at the disposal of the organizations that belong to our sample.

- Consequences of controls carried out by control bodies: This section was interested in showing the impact of the different levels of controls carried out by the company on the implementation of an efficacious internal control system.

Prior to our visit to the internal auditors and the internal controllers, we addressed them an email in which we indicated the purpose of the interview and the main axes to be discussed. Those interviews lasted 1 month and took on average one hour with each auditor or controller. They were conducted in French language.

During our interviews, we had used the audio recording in order to keep all the details about the interviews conducted with internal auditors and controllers, which helped us in the analyse of data collected.

\section{3 Sample selection and description:}

This study was based on a sample of 10 Moroccan publicly traded companies operating in a variety of industries. The size and the composition of our sample were based on two criteria, amongst we find: the diversification and the empirical saturation[23].

The criterion of diversification allowed us to obtain a certain representativeness of the main activity sectors where the publicly traded companies operate.

The saturation criterion allowed us to stop at the level at which we judged that our surveys do not bring new information or additional data, compared to what has already been collected.

It is from the 8th interview that the information gathered has proved to be already dealt with in the previous interviews, and will not bring any additional information to our subject.

\subsection{Data processing and analysis of results:}

After conducting semi-structured interviews with the 10 listed companies, we started analyzing the data collected on the basis of the audio recordings made. Our analysis had gone through several steps among which we find;

The retranscription of the data: The transcription was the first step used to analyze the content of the interviews, it consisted in listing the information collected by putting them in text form "verbatim" which represents the raw data of the investigation. In other words, the retranscription organizes the 
survey material in a format directly accessible to analysis, rather than dealing directly with audio or video recordings (Auerbach, Silverstein, 2003, cited by Andreani and Conchon, 2005)

Semantic processing: in this step, we had used the evaluation analysis, that enabled us to examine the speaker's judgments from the point of view of frequency and direction, thus, we were able to note several judgments that led to the assertion that internal audit contribute to the improvement of internal control system.

The processing of the data collected through this survey led to the results presented as follows.

Certain internal controllers who represent $63 \%$ of the sample selected, asserted that the first-level controls, provided by operational staffs and their hierarchies, which cover day-to-day controls, do not protect the organization against the inherent risks. An internal controller declared: " the first level of control which contains all the operations of checks and controls carried out by the $n+1$ hierarchical level operatives, allowing to ensure the application of procedures and regulations are not sufficient, and do not allow the organization to control its risky operations and detect fraudulent acts, considering the high probability of connivance that may exist between the operative controlled and his hierarchical superior".

According to the interviews conducted with these controllers, we concluded that a higher level of control is necessary to better cover the risks that cannot be mastered by the first level controls.

These internal controllers suggested that this control must be carried out by a none operational direction. It consists in regularly ensuring that the first level controls are carried out and are effective, and that the procedures are well applied.

In fact, these controls are done by the internal control department, which is a system implemented by the company, that has as a purpose to control risky operations. An internal controller said: "The internal control system set up by the company allows to struggle against fraud, particularly the fraud discovered at the level of the financial states, and participates in the installation of a more efficient and more competitive system ".

The internal control system is responsible for increasing the reliability of financial information, by fighting fraud and ensuring compliance with regulations and laws.

It contributes, in their opinion, to the control of the organization's activities, to the efficiency of its operations and the optimization of its resources. The internal control responsibility is linked to all hierarchical levels within an organization; both employees and the top management are concerned. 
To this end, the organization staff must ensure the application of the instructions given to them, and the top management or the general management must put in place sufficient control devices as part of instructions given to the staff.

In addition, $70 \%$ of the respondents affirmed that certain internal control rules are primordial to maintain a good internal control system.

These rules consist in the separation of functions, it means that one person must not be at the same time the person in charge of an action and the controller of its execution.

Furthermore, all transactions carried out within a company must be monitored and recorded with their supporting documents, in order to be reconstituted thereafter. These operations must also be secured in order to make easier their restoration in case of incident.

However, an internal auditor stated that " Just few number of internal controllers who check the application of these rules. These good practices are completely ignored, and it is for this reason that a higher level control is strongly needed in order to put things back in their places "

Thus, according to the interviews led with the internal auditors of the companies that belong to our sample, it has been revealed that internal control has some limits, that can make its status fallible and insufficient to maintain the performance of an organization, considering that it provides only a reasonable and not an absolute insurance on the achievement of the organization objectives. Indeed, internal control can under no circumstances transform a bad manager into a good manager.

According to these assertions, we can say that the strengthening of the internal control role depends absolutely on the existence of a higher level entity, which purpose is the supervision and the evaluation of the internal control system, and the issuance of an internal control report.

The interviews conducted with these internal auditors enabled us to identify the important role of the Internal Audit function within organizations, since the controls carried out by this entity allow the detection and the determination of risky situations, in order to propose recommendations to reduce them, and to contribute to the continued effectiveness of the internal control system;

In reply to the question concerning how internal audit contributes to the improvement of internal control system, the internal auditor of a large company declared that "To establish an effective internal control system and prevent fraud, the internal audit department must perform punctual controls allowing to reduce the risk to a very low level, in order to obtain reasonable insurance on the proper functioning of all the organization's processes ".

The internal auditor will therefore verify that the internal control rules are effectively applied and deliver the expected results. 
Internal audit is a strong signal through which the organization shows the importance of internal control, and it is a means of monitoring and controlling the effectiveness of internal control system.

Besides, internal auditors are expected to provide regular information on the functioning of internal control, by evaluating its conception and its operations. They should communicate information on the strengths and weaknesses of internal control system and provide recommendations for improvement.

To this end, and in order to be effective, the internal audit entity must be independent of the operational departments and work impartially, thereby, it must report directly to the audit committee and by then to the top management.

\section{Conclusion:}

The interviews conducted with internal controllers and internal auditors through our qualitative study allowed us to explore the different control levels within the organisation, and their important contribution to the protection of the internal control system against fraud, errors and nonprofitability or waste, that may hamper the achievement of organizational goals and make it less effective.

More particularly, the internal audit function was judged to be the most important control fuction, due to the interesting role that plays in terms of monitoring the internal controls of an organization. A great number of auditors interviewers considered it as a means of monitoring and piloting the effectiveness of internal control, and a way of detection of risky operations, in order to offer recommendations allowing to diminish these risks, and to contribute to the continuous effectiveness of the internal control system.

In addition to their role in monitoring the internal controls of an organization, competent and independent internal auditors can contribute to the effectiveness of the external audit missions by providing direct assistance to the external auditor. This one can rely on internal audit reports and works so as to reduce the scope of audit work, and to avoid unnecessary duplication.

\section{Notes:}

1. INTOSAI, the International Organization of Supreme Audit Institutions operates as an umbrella organization for the external government audit community. This organization has conceived a guideline for internal control standards for the public sector, from which we have taken the definition of internal control.

2. IIA, the Institute of Internal Auditors is an institute which mission is to establish the professional standards of internal audit. 
3. IFACI, the french institute of internal auditors and controllers, is the frensh chapter of IIA (The institute of Internal Auditors). It has as an objectif to ensure the dynamic leadership of the internal audit profession.

4. The Structural Adjustment Programs are the economic policies which countries must follow in order to qualify for new World Bank and International Monetary Fund loans, and help them make debt repayments on the older debts owed to commercial banks, governments and the World Bank.

5. AMACI, the Moroccan Association of Internal Auditors and Controllers is an association created in 1985, it is an adherent member of the Institute of Internal Auditors, and a founding member of Francophone Union of Internal Auditors in 1989. It is also a member of the European Confederation of Internal Audit Institutes from 1997. This association aims at developping the internal audit function within the Moroccan public and private organizations.

6. FRAP is the french acronym of Revelation and Problem Analysis Sheets. It constitutes the internal audit technique that allows the auditor to analyse deficiencies detected, by dividing them in five parameters, amongst we have: the problem, the audit finding, the causes, the consequences and the recommendations.

\section{References:}

1. Fr, V.A.N.S.T.A.P.E.L. (2001). Lignes directrices sur les normes de contrôle interne à promouvoir dans le secteur public. [En ligne] Disponible: http://www.partagedesconnaissancesbw.be/attachment/425249/

2. Fr, V.A.N.S.T.A.P.E.L. (2001). Guidelines of Internal Control Standards to Promote in the Public Sector. [online] Available: http://www.partagedesconnaissancesbw.be/attachment/425249/

3. Elisabeth, B. E. R. T. I. N. (2007). Audit interne: enjeux et pratiques à l'international. Editions d'Organisation Eyrolles.

4. Elisabeth, B. E. R. T. I. N. (2007). Internal audit: international issues and practices. Editions d'Organisation Eyrolles.

5. Najah, E. (2016). Les Déterminants de l'Indépendance De l'Auditeur. European Scientific Journal, ESJ, 12(34).

6. Najah, E. (2016). The determinants of the Auditor Independence . European Scientific Journal, ESJ, 12(34).

7. Barnia, M. (2015). La création de valeur ajoutée socio-économique par L'Audit Interne: Cas d'Entreprises Marocaines(Doctoral dissertation, Conservatoire national des arts et metiers-CNAM).

8. Barnia, M. (2015). The creation of socio-economic added value by the Internal Audit: Case of Moroccan Enterprises (Doctoral dissertation, Conservatoire national des arts et metiers-CNAM). 
9. Olivier, L. E. M. A. N. T. (2003). l'audit interne, édition e-theque.

10. Olivier, L. E. M. A. N. T. (2003). internal audit, édition e-theque.

11. Reding, K. F. (2015). Manuel d'audit interne: améliorer l'efficacité de la gouvernance, du contrôle interne et du management des risques. Editions Eyrolles.

12. Reding, K. F. (2015). Internal audit manual: improving the effectiveness of governance, internal control and risk management. Editions Eyrolles.

13. Bécour, J. C., \& Bouquin, H. (1996). Audit opérationnel: efficacité, efficience ou sécurité. Economica.

14. Bécour, J. C., \& Bouquin, H. (1996). Operational audit: efficiency, effectiveness or security. Economica.

15. Renard, J. (2016). Théorie et pratique de l'audit interne: Primé par l'IFACI. Editions Eyrolles.

16. Renard, J. (2016). Theory and Practice of Internal Audit: Awarded by IFACI. Editions Eyrolles.

17. IFACI. (2013). Cadre de Référence International des Pratiques Professionnelles de l'Audit Interne.1-255.

18. IFACI. (2013). International Reference Framework of Professional Practices of Internal Audit.1-255.

19. Schick, P. (2007). Memento d'audit interne: Méthode de conduite d'une mission. Dunod.

20. Schick, P. (2007). Memento of internal audit: Method of conducting a mission. Dunod.

21. Mandzila, E. E. W. (2006). Audit interne et gouvernance d'entreprise: lectures théoriques et enjeux pratiques. Euromed-Marseille Ecole de Management.

22. Mandzila, E. E. W. (2006). Internal audit and corporate governance: theoretical readings and practical issues. Euromed-Marseille Ecole de Management.

23. Ebondo Wa Mandzila, E. (2004). La contribution du contrôle interne et de l'audit au gouvernement d'entreprise (Doctoral dissertation, Paris 12).

24. Ebondo Wa Mandzila, E. (2004). The contribution of internal control and audit to corporate governance (Doctoral dissertation, Paris 12).

25. Jensen, M. C., \& Meckling, W. H. (1976). Theory of the firm: Managerial behavior, agency costs and ownership structure. Journal of financial economics, 3(4), 305-360.

26. Charreaux, G. (2000). Gouvernement d'entreprise et comptabilité. Encyclopédie de comptabilité, contrôle de gestion et audit, 645-656. 
27. Charreaux, G. (2000). Corporate governance and accounting. Encyclopedia of accounting, management control and audit, 645-656.

28. Gramling, A. A., \& Myers, P. M. (2006). Internal auditing's role in ERM: as organizations lay their enterprise risk groundwork, many auditors are taking on management's oversight responsibilities, new research finds. Internal Auditor, 63(2), 52-58.

29. Hanim Fadzil, F., Haron, H., \& Jantan, M. (2005). Internal auditing practices and internal control system. Managerial Auditing Journal, 20(8), 844-866.

30. Ebondo Wa Mandzila, E. (2007). Internal Audit and Corporate Governance: Theoretical Readings and Practical Issues (Audit Interne Et Gouvernance D'Entreprise: Lectures Théoriques Et Enjeux Pratiques).

31. Gramling, A. A., Maletta, M. J., Schneider, A., \& Church, B. K. (2004). The role of the internal audit function in corporate governance: A synthesis of the extant internal auditing literature and directions for future research. Journal of Accounting literature, 23, 194.

32. Ho, S., \& Hutchinson, M. (2010). Internal audit department caracteristics/activities and audit fees: Some evidence from Hong Kong firms. Journal of International Accounting, Auditing and Taxation, 19(2), 121-136.

33. Coram, P., Ferguson, C., \& Moroney, R. (2008). Internal audit, alternative internal audit structures and the level of misappropriation of assets fraud. Accounting \& Finance, 48(4), 543-559.

34. Thiétart, R. A. (2014). Méthodes de recherche en management-4ème édition. Dunod.

35. Thiétart, R. A. (2014). Research Methods in Management-4th Edition.Dunod.

36. Barlow P., Helberg S., Large N., et Le Roux K.(1995), "The Business Approach to

37. Internal Auditing », Juta\&Co, Ltd, republic of South Africa.

38. Wiley, Canada, 2009.utissier D. (2001), " Nature des changements produits par une mission d'audit interne",

39. Comptabilité- Contrôle -Audit, tome 7, volume 2, novembre 2001, pp.87 à 103).

40. Autissier D. (2001), “Nature des changements produits par une mission d'audit interne", Comptabilité- Contrôle -Audit, tome 7, volume 2, novembre 2001, pp.87 à 103).

41. Autissier D. (2001), "Nature des changements produits par une mission d'audit interne", Comptabilité- Contrôle -Audit, tome 7, volume 2, novembre 2001, pp.87 à 103). 
42. Autissier D. (2001), "Nature des changements produits par une mission d'audit interne", Comptabilité- Contrôle -Audit, tome 7, volume 2, novembre 2001, pp.87 à 1 